\title{
BÁRBARA E YANSÃ EM $O$ SUMIÇO DA SANTA: UMA HISTÓRIA DE FEITIÇARIA, DE JORGE AMADO
}

\author{
Edilece Souza Couto* \\ Universidade Federal da Bahia - UFBA \\ edilece@ufba.br
}

\begin{abstract}
RESUMO: A imagem de Santa Bárbara, a do trovão, embarca no saveiro em Santo Amaro da Purificação, recôncavo da Baía de Todos os Santos, em direção a Salvador para ser a peça principal de uma exposição de arte religiosa. Na rampa do mercado, a santa sai do andor e transforma-se em Yansã. O orixá veio à Bahia para fazer justiça e, para encontrar seus filhos, manifesta-se em festas e terreiros de candomblé. Esse é o enredo do livro O sumiço da santa, publicado por Jorge Amado em 1988. Este artigo tem como objetivo analisar, por meio da literatura, as crenças afro-brasileiras e católicas ligadas aos cultos da santa e do orixá na cidade do Salvador.
\end{abstract}

PALAVRAS-CHAVE: Santa Bárbara - Yansã - O sumiço da santa - Jorge Amado - Bahia

\section{BARBARA AND YANSÃ IN THE WAR OF THE SAINTS: A WITCHCRAFT STORY BY JORGE AMADO}

\begin{abstract}
The holy icon of Santa Barbara of the Thunder was boarded a sloop in Santo Amaro da Purificação, at Todos os Santos Bay, towards Salvador to be the main piece in a religious art exhibition. At the market ramp, the icon leaves the litter and becomes Yansã. The orisha had gone to Bahia to make justice and, in order to find her children, she manifests in festivities and candomble temples. This is the plot of the book The War of the Saints, published by Jorge Amado in 1988. This paper aims to analyze, by means of literature, the African-Brazilian and catholic beliefs related to the worship of both the saint and the orisha in the city of Salvador.
\end{abstract}

KEYWORDS: Santa Barbara - Yansã - The War of the Saints - Jorge Amado - Bahia

\footnotetext{
* Professora associada do departamento de História da Universidade Federal da Bahia - UFBA. Realizou pós-doutorado no Programa de Pós-Graduação em História da Universidade Estadual de Maringá - UEM, doutorado e mestrado em História pela Universidade Estadual Paulista - UNESP, campus de Assis-SP; pesquisa na área da História das Religiões e das Religiosidades, com ênfase no cristianismo, nas associações leigas católicas e suas festas.
} 


\section{Oh, Bahia da magia \\ Dos feitiços e da fé \\ Bahia que tem tanta igreja \\ Que tem tanto candomblé (Herivelto Martins/Chianca de Garcia. A \\ Bahia te espera)}

Em 2018 fez trinta anos que Jorge Amado publicou O sumiço da santa, livro planejado vinte anos antes e que seria intitulado "A guerra dos santos" (adotado na edição em inglês), um dos quatro títulos que o autor dispõe nas paginas iniciais. Além do oficial e deste primeiro, ele ainda o chama de "Visitação de Yansã à cidade da Bahia" e "Execração pública de fanáticos e puritanos".

\section{O ESCRITOR, O TEMPO E O CONTEXTO}

Jorge Leal Amado de Faria ${ }^{1}$ nasceu na fazenda Auricídia (município de Ilhéus), mas foi registrado no povoado de Ferradas - distrito de Itabuna, no sul da Bahia, em 1912. Era o filho mais velho de Eulália Leal e João Amado de Faria. Passou a infância em Ilhéus. Aos 11 anos foi morar em Salvador como aluno interno do Colégio Antônio Vieira, dirigido pelos jesuítas. Estudou também no Colégio Ipiranga, onde fazia parte da Academia dos Rebeldes com publicação de jornais e revistas com textos literários. Freqüentava os terreiros de candomblé e via de perto a violência enfrentada pelos candomblecistas, umbandistas, cristãos não católicos e espíritas.

Em 1930, Jorge Amado foi morar no Rio de Janeiro. O pai queria ver o filho “doutor". Formou-se bacharel em Direito, mas nunca exerceu a profissão. Filiou-se ao Partido Comunista do Brasil - PCB em 1932, sendo eleito deputado por São Paulo em 1946, embora a tribuna não lhe parecesse agradável. Da breve atividade parlamentar tinha um orgulho: a proposta de emenda na Assembléia Constituinte em favor da liberdade religiosa. Mesmo sem o apoio dos colegas comunistas, conseguiu o aval de Carlos Prestes e as assinaturas de deputados de diferentes filiações partidárias. Assim, a emenda parlamentar foi transformada em artigo de lei na Constituição de 1946. Com a

1 Ver a primeira biografia de Jorge Amado publicada em 12 de novembro de 2018. AGUIAR, Josélia. Jorge Amado: uma biografia. São Paulo: Todavia, 2018. 681 p. 


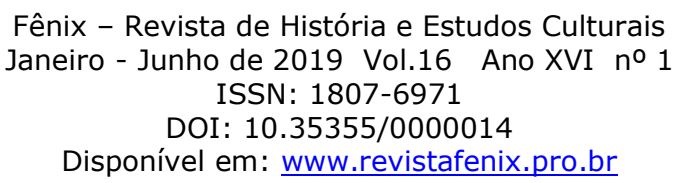

imposição da clandestinidade ao PCB, cassação de todos os mandatos, prisão e exílio de seus membros, Jorge e família ficaram exilados ${ }^{2}$ em Paris - França (de 1948 a 1950) e em Dobris (de 1950 a 1952), na época Tchecoslováquia e atual República Tcheca.

A família Amado retornou ao Brasil em 1952. Jorge Amado e Zélia Gattai ${ }^{3}$ planejavam uma mudança do Rio de Janeiro para Salvador. Queriam criar os filhos João Jorge e Paloma numa cidade menor e mais calma. Entre 1961 e 1963 fizeram várias viagens ao Nordeste, aproximaram-se de amigos baianos e pernambucanos, a fim de efetivar a compra de uma casa na capital baiana e fixar residência. Compraram um terreno na Rua Alagoinhas, n³3, no bairro do Rio Vermelho. Em 1963 construíram a casa, habitada pelo casal até 2001 (ano da morte de Jorge) e por Zélia até 2003 quando passou a morar em outra casa até 2008, ano de sua morte. A Casa do Rio Vermelho foi transformada em memorial em 2014.

Nos limites desse artigo, apresento poucos dados biográficos de Jorge Amado, especialmente os relacionados às religiões. Nas primeiras páginas do livro $O$ sumiço $d a$ santa, o escritor situa a sua história de feitiçaria na cidade do Salvador e afirma que "A importância da data é relativa", mas que "tudo se passou num tempo curto de quarenta e oito horas, longo de vidas vividas, ao término dos anos sessenta e nos começos dos anos setenta, por ai, assim". ${ }^{4} \mathrm{O}$ enredo deste romance conta o sumiço de uma imagem sacra católica e as aventuras do orixá Yansã na capital da Bahia. A imagem de Santa Bárbara, a do trovão, embarca no saveiro em Santo Amaro da Purificação, recôncavo da Baía de Todos os Santos, em direção a Salvador para ser a peça principal de uma exposição de arte religiosa. Na rampa do mercado, a santa sai do andor e transforma-se em Yansã. O orixá veio à Bahia para fazer justiça e, para encontrar seus filhos, manifesta-se em festas e terreiros de candomblé.

Zélia Gattai, esposa de Jorge Amado e memorialista, escreveu sobre a memória do exílio no livro Jardim de Inverno, também publicado pela editora Record, em 1988. Cf. GATTAI, Zélia. Jardim de inverno: memórias. São Paulo: Companhia das Letras, 2009. (Arquivo Kindle).

3 Zélia Gattai escreveu sobre a mudança da família Amado para Salvador no início da década de 1960, e relata o cotidiano na Casa do Rio Vermelho, onde passaram a residir, a receber os amigos (artistas, intelectuais e escritores do mundo inteiro), assim como as viagens do casal e a escrita dos livros. Livro publicado pela Record em 1999. Neste artigo utilizo a versão digital: GATTAI, Zélia. A casa do Rio Vermelho: memórias. São Paulo: Companhia das Letras, 2010. (Arquivo Kindle).

4 AMADO, Jorge. O sumiço da santa: uma história de feitiçaria. Rio de Janeiro: Record, 1988. p. 11. 
Não há obrigatoriedade de precisão do tempo ${ }^{5}$ na Literatura. Porém, a História está centrada no tempo lógico. Paul Ricoeur define a História como uma meditação do viver humano no tempo e afirma que deve haver uma interação entre o vivido e a lógica, a constituição de uma intriga, por meio de uma história-problema. Nesse sentido, Michel de Certeau propõe um discurso historiográfico que inclua os seus "outros", os discursos de outros tempos vividos, no diálogo com as fontes. Esse discurso aparece como produto de um lugar social, uma prática, uma escrita. $\mathrm{O}$ historiador é um construtor de texto tal qual um literato, embora sua escrita tenha uma metodologia baseada nas fontes. A História é ficção não por ser imaginada, mas por ser construção.

Entretanto, o historiador pode utilizar alguns elementos da narrativa literária para avaliar o contexto histórico no qual as cenas foram ambientadas. E Jorge Amado nos dá algumas pistas. Ele afirma que o padre da Igreja de Santo Amaro da Purificação, guardiã da famosa imagem de Santa Bárbara, a do trovão, não queria emprestá-la para a exposição no Museu de Arte Sacra - MAS de Salvador.

O museu é um importante marco nesse recorte temporal. Ele foi organizado pela equipe da Universidade Federal da Bahia durante a gestão do seu primeiro reitor, Edgar Santos, entre 1946 e 1961. O reitor fez da UFBA um espaço de vanguarda das artes, especialmente com a criação das Escolas de Música, Teatro e Dança. A fim de acolher, preservar e expor as obras de arte sacra da Bahia foi escolhida uma construção seiscentista, originalmente convento dos carmelitas descalços e seminário episcopal de 1837 a 1956. Portanto, a narrativa da exposição de arte religiosa pode ser demarcada nos anos a partir de 1959, ano da fundação do MAS.

Entre as décadas de 1950 e 1960 houve a criação do cinema novo baiano, trio elétrico e tropicalismo. Segundo Armindo Bião essas novidades foram possíveis em função das "boas relações entre tradição, novas tecnologias e comércio", capazes de tecer uma "configuração cultural singular e única que definiria a baianidade" como uma forma "claramente mestiça". ${ }^{6}$ Milton Moura $^{7}$ entende a baianidade como um texto

5 Sobre as discussões sobre o tempo e a relação Literatura e História, ver RICOEUR, Paul. Tempo e narrativa. São Paulo: Papirus, 1994; CERTEAU, Michel de. A escrita da História. Rio de Janeiro: Forence Universitária, 2000. 350 p.

6 BIÃO, Armindo. Matrizes estéticas: o espetáculo da baianidade. In: BIÃO, A; et al. Temas em contemporaneidade, imaginário e teatralidade. São Paulo: Annablume; Salvador: JIPE-CIT, 2000, p. 22. 
identitário, com a afirmação categórica e o enunciado de um perfil de sujeito ou de sociedade numa dinâmica de identificação, baseado em três pilares: familiaridade, sensualidade e religiosidade. Trata-se da ambivalência de uma sociedade desigual com a naturalização de papéis e posturas e a mistificação da sociedade tradicional.

Dessa forma foi construída uma imagem da Bahia como terra de magia, encantos, encantados e feitiçaria, e de um jeito de ser baiano mestiço, feliz e festeiro. No entanto, podemos encontrar as representações da baianidade desde os anos de 1930, principalmente na música composta por brasileiros nascidos em outras regiões, mas que viam a Bahia como lugar ancestral. $\mathrm{Na}$ voz, na indumentária e nos requebros de Carmem Miranda (portuguesa de nascimento), o mundo conheceu o tabuleiro da baiana e a Baixa dos Sapateiros. Nos mais diversos pontos do Brasil das décadas de 1940 e 1950, as canções sobre a Bahia, nas vozes de Dorival Caymmi, Ciro Monteiro, Francisco Alves, Herivelto Martins e Dalva de Oliveira, chegavam pelas ondas do rádio. $^{8}$

Porém, é inegável que os elementos da baianidade tiveram maior visibilidade, publicidade e conotação política a partir dos anos 1960. Havia um ambiente criativo que contribuiu para o surgimento de alguns artistas baianos, como o cineasta Glauber Rocha, os compositores e cantores Gilberto Gil e Caetano Veloso, e a confluência de tantos outros para Salvador, como o fotógrafo francês Pierre Verger, que se fixou em Salvador em 1946, após ler Jubiabá, de Jorge amado, e se dedicou a registrar, por meio da fotografia e da escrita de livros, o cotidiano, as festas e as práticas religiosas do povo negro, afro-descendente e de santo da Bahia; o artista plástico argentino Hector Julio Paride Bernabò, mais conhecido por Carybé, em 1950, e ilustrou com desenhos livros de Jorge Amado, como O sumiço da santa; o pintor e desenhista Floriano Teixeira, em 1965, que também ilustrou livros de Jorge Amado; o compositor e cantor carioca Vinicius de Morais. A amizade e a familiaridade com esses artistas e suas obras também influenciaram o retorno à Bahia de Jorge Amado, em 1963.

Após 1960, parte das elites ocupantes de cargos públicos, políticos e administrativos, e setores do empresariado absorveu e reelaborou os elementos

7 MOURA, Milton Araújo. Carnaval e baianidade: arestas e curvas na coreografia de identidades do carnaval de Salvador. Tese de doutorado (Comunicação e Cultura Contemporâneas), Universidade Federal da Bahia - UFBA, 2001, p. 06-10.

8 Ibid., p. 141-143. 
simbólicos da baianidade na forma de propaganda midiática da Bahia como "Terra da Felicidade”. Não há lugar para a miséria, e sim, para mostrar o que é belo. Isso significou a consolidação do discurso da baianidade para fins políticos, principalmente nas gestões de Antônio Carlos Magalhães como prefeito de Salvador (1967-1971) e governador da Bahia (1971-1975). Em 1974, foi criada a Fundação Cultural do Estado da Bahia - FUNCEB para planejar, coordenar e promover as ações culturais do Estado. ${ }^{9}$

Foi nesse contexto que o calendário das festas religiosas de Salvador ganhou destaque nos jornais e TVs. Os cortejos festivos aos santos, orixás e caboclos, encarados como exterioridades da fé até o século XIX, passaram a ser vistos como momentos propícios para atrair turistas e propagar a Bahia no Brasil e no mundo com terra mística, cultural e turística. Nos jornais de Salvador eram publicadas reportagens sobre os festejos e as associações entre santos e orixás. E os políticos em busca de visibilidade eram juízes das festas e colaboravam com recursos para que elas fossem realizadas com pompa. $^{10}$

Os livros de Jorge Amado, mesmo antes desse período, já eram marcados pelos elementos da baianidade. Moura enxerga na obra do escritor, assim como na de Caymmi, a "benignidade do mundo e da natureza", onde os personagens enfrentam a mata (para plantar cacau no sul baiano) ou o mar da Bahia. São os desafios para sobreviver diante de "trabalho, natureza, amor e luta", temas sempre presentes nos pilares da baianidade, embora esta seja uma referência para Salvador e Recôncavo. As outras regiões do Estado têm outras identidades e culturas.

Jorge Amado forma uma espécie de confraria de artistas baianos, reunidos na Casa do Rio Vermelho, e dava seus nomes e emprestava suas características aos personagens. O sumiço da santa é cheio de referências às obras de arte e aos livros escritos pelos amigos do escritor, assim como ao povo de santo com quem ele mantinha amizade e familiaridade. Não há valorização da família convencional e consangüínea, como a que desejava a personagem Adalgisa, e sim, daquelas formadas pelos laços espirituais, de santo.

9 DANTAS NETO, Paulo Fábio. Tradição, autocracia e carisma: a política de Antonio Carlos Magalhães na modernização da Bahia (1954-1974). Belo Horizonte: UFMG / IUPERJ, 2006, 588 p.

10 COUTO, Edilece Souza. Bárbara e Iansã, as donas dos mercados de Salvador. In: RUBIM, Linda; MIRANDA, Nadja (Orgs.). Estudos da festa. Salvador: EDUFBA, 2012. p. 111-131. 


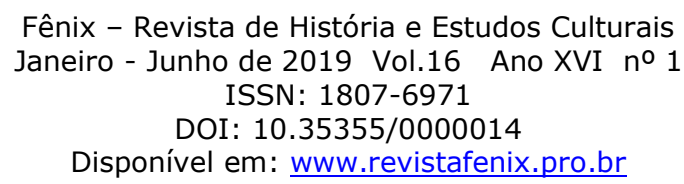

A sensualidade está presente nos personagens centrais. São mulheres sensuais Gabriela, Dona Flor, Tereza Batista, Tieta, etc. Em $O$ sumiço da santa, é preciso salientar os traços sensuais da jovem Manela e mesmo da sua tia Adalgisa, que, apesar de ser católica fervorosa, beata e ter casado virgem, se revela ardente nas cenas da sua segunda lua de mel, após Yansã lhe libertar das amarras morais do catolicismo. Nesse livro, sensuais também são os homens: Miro, o taxista e namorado de Manela, e Danilo, o ex-jogador de futebol, esposo de Adalgisa. Segundo Moura,

É sobretudo em $O$ Sumiço da Santa, o último romance propriamente dito, que o autor tudo reúne e compatibiliza. Conventos, candomblés e castelos; padres e mães de santo; dondocas e prostitutas; os lugares mais diferentes da cidade; e dezenas de amigos e amigas, entre os quais músicos, artistas plásticos, políticos e personagens muito especiais como Dona Canô. ${ }^{11}$

O aceite da solicitação para expor a imagem de Santa Bárbara, a do trovão, no MAS só foi dado pelo padre de Santo Amaro da Purificação a muito custo e sob a pressão do cardeal. O escritor não dá nome fictício nem real ao personagem, o que poderia ter feito, uma vez que determinadas personalidades da Bahia figuram em seus romances e enredos, a exemplo de Dona Canô ${ }^{12}$, devota de Nossa Senhora da Purificação. É a respeitada católica santamarense, que, juntamente com o vigário e o sacristão, embarca a imagem da Santa no cais de Santo Amaro.

Identificar o Cardeal seria tarefa mais complicada, pois entre os anos de $1960 \mathrm{e}$ 1970, o Arcebispado da Bahia teve três cardeais: dom Augusto Álvaro da Silva (19241968), ordenado cardeal em 1953; dom Eugênio de Araújo Sales (1968-1971), em 1969; e dom Avelar Brandão Vilela (1971-1986), em 1973. Interessante notar que Jorge Amado não deu nome ao personagem, mas privilegiou a honraria do cardinalato. Ele poderia ter registrado o Arcebispo, mas preferiu chamá-lo de Cardeal, o que insere muito bem sua trama na Bahia da segunda metade do século XX. Dom Augusto foi o

11 MOURA, Milton Araújo. Carnaval e baianidade: arestas e curvas na coreografia de identidades do carnaval de Salvador. Tese de doutorado (Comunicação e Cultura Contemporâneas), Universidade Federal da Bahia - UFBA, 2001, p. 160.

12 Claudionor Viana Teles Velloso (1901-2012), nascida em Santo Amaro da Purificação, casada com José Teles Velloso (seu Zeca), teve seis filhos, sendo os mais conhecidos a poetisa e escritora Mabel Veloso, o compositor e cantor Caetano Veloso e a cantora Maria Bethânia. Ver FREITAS, Antônio F. Guerreiro de; SILVA, Artur Assis G. da. Canô Velloso: lembranças do saber viver. Salvador: EDUFBA, 2009. 214 p. 


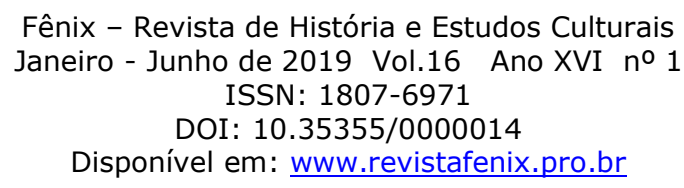

primeiro arcebispo da Bahia e primaz do Brasil a ser ordenado cardeal. A partir de 1953 ele passou a ser conhecido como Cardeal da Silva. Assim, como dignidade está acima de arcebispo na hierarquia católica, a denominação cardeal tinha mais peso e prestígio.

A mudança da família Amado para Salvador aproximou ainda mais o escritor da cultura e da pluralidade de crenças religiosas da Bahia. Chama atenção o fato de Jorge Amado não ter incluído o Ilê Axé Opó Afonjá entre um dos terreiros visitados por Yansã, afinal era o mais freqüentado por ele. No período em que situa o romance, o terreiro passava por mudanças. Mãe Senhora ${ }^{13}$ faleceu em 1967. Jorge estivera com ela na véspera, acompanhou seu velório na Igreja da Ordem Terceira do Rosário de Nossa Senhora às Portas do Carmo (mais conhecida como Irmandade dos Homens Pretos) e o enterro no Cemitério Quinta dos Lázaros. Realizados os ritos fúnebres, o terreiro só teve nova iyalorixá, Mãe Ondina ${ }^{14}$ de Oxalá, em 1969. Provavelmente, o escritor em respeito ao período de luto, não quis incluir o terreiro no enredo.

O terceiro pilar da baianidade, a religiosidade, está presente em várias obras de Jorge Amado, mas a sua própria vivência no candomblé tornou-se mais freqüente e profunda. Na amizade com os adeptos do candomblé, especialmente com obás, pais e mães de santo, e a participação nas atividades dos terreiros, acumulou conhecimento para construir seus personagens candomblecistas e descrever, com riqueza de detalhes, os cenários, as festas, os ritos e as práticas religiosas afro-brasileiras.

\section{CREnÇAS E RELIGIÕES HÍBRIDAS}

Apesar de se identificar como materialista, Jorge Amado era Obá de Xangô, título honorífico estabelecido pela iyalorixá Aninha ${ }^{15}$, do terreiro Ilê Axé Opó Afonjá. Os ministros de Xangô eram amigos, protetores e divulgadores do candomblé. Assim, Jorge e Zélia passaram a ser freqüentadores assíduos das festas e ritos do terreiro.

13 Maria Bibiana do Espírito Santo (1890-1967) foi iniciada em 1907 por Mãe Aninha e foi iyalorixá do Ilê Axé Opó Afonjá de 1942 a 1967. Tinha barraca na rampa do Mercado Modelo, no qual Camafeu de Oxóssi, seu filho de santo, tinha barraca, conheceu Jorge Amado e o apresentou a Mãe Senhora.

14 Ondina Valéria Pimentel (1916-1975) foi a quarta iyalorixá do Ilê Axé Opó Afonjá.

15 Eugênia Anna Santos (1869-1938), da nação Ketu, foi a fundadora do Ilê Axé Opó Afonjá em Salvador, em 1910. Junto com Martiniano Eliseu do Bonfim instituiu o Corpo de Obás de Xangô. Em 1937 participou do II Congresso Afro-Brasileiro, realizado na capital baiana. Seu velório aconteceu na Ordem Terceira do Rosário de Nossa Senhora às Portas do Carmo, confraria dos homens pretos, e o sepultamento no cemitério Quinta dos Lázaros na ala da Irmandade de São Benedito. 


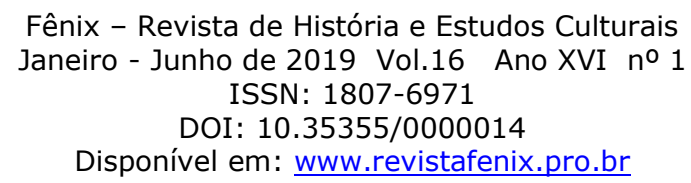

Faziam o bori ${ }^{16}$ anual. Zélia, no livro A Casa do Rio Vermelho, conta como foi a noite ritual de 1963, no terreiro naquele momento comandado por Mãe Senhora. ${ }^{17}$

Foi idéia de Jorge colocar um $\operatorname{Exu}^{18}$ (confeccionado de ferro pelo mestre artesão Manu) no jardim da nova casa, para ser o guardião da mesma. Mãe Senhora não viu a representação simplesmente como um elemento decorativo e providenciou o assentamento do mensageiro dos deuses com sangue de galo preto, farofa de dendê, charutos e cachaça. A iyalorixá ainda deixou com Zélia a obrigação de toda segunda-feira ofertar meio copo de cachaça ao compadre.

Na década de 1980, quando Jorge Amado escreveu $O$ sumiço da Santa, os cientistas sociais repensavam as junções, fusões e misturas entre as culturas e as religiões. Revisavam o termo sincretismo, empregado como um processo de aculturação, acomodação e assimilação. Rejeitavam o sincretismo como disfarce de práticas para enfrentar a dominação colonial e do catolicismo, enquanto religião de estado, e também como resistência. ${ }^{19}$

Vem da Bahia, particularmente da iyalorixá Stella ${ }^{20}$ de Oxóssi a primeira manifestação contra o sincretismo por parte de uma autoridade das religiões afrobrasileiras. Entre os dias 17 e 23 de julhô de-1983 aconteceu em Salvador a II Conferência Mundial de Tradição dos Orixás e Cultura. Nesse evento, Mãe Stella fez seu primeiro pronunciamento público contra o sincretismo afro-católico. E, no dia 27 do mesmo mês e ano, para reafirmar a constatação de que o candomblé é "uma religião

16 Bori, em ioruba, significa dar comida à cabeça. A oferenda harmoniza a cabeça material com a espiritual, afastando a ansiedade, o medo, a dor e propicia a esperança e a alegria. A pessoa toma banho de folhas, veste roupas brancas, assiste à matança das galinhas e à preparação da comida e passa a noite literalmente com a comida na cabeça, segura pelo torço. Sobre o bori de Jorge e Zélia, ver GATTAI, Zélia. A casa do Rio Vermelho: memórias. São Paulo: Companhia das Letras, 2010. (Arquivo Kindle, posição 848-879).

17 Maria Bibiana do Espírito Santo (1890-1967) foi iniciada em 1907 por Mãe Aninha e foi iyalorixá do Ilê Axá Opó Afonjá de 1942 a 1967. Tinha barraca na rampa do Mercado Modelo, no qual Camafeu de Oxóssi, seu filho de santo, tinha barraca, conheceu Jorge Amado e o apresentou a Mãe Senhora.

18 Zélia relata o assentamento de Exu no capítulo "Exu, meu compadre". Ver GATTAI, Zélia. A casa do Rio Vermelho: memórias. São Paulo: Companhia das Letras, 2010. (Arquivo Kindle, posição 11141127).

19 FERRETTI, Sérgio Figueiredo. Repensando o sincretismo: estudo sobre a Casa das Minas. São Paulo: EdUsp / São Luís: FAPEMA, 1995. 234 p.

20 Maria Stella de Azevedo Santos, nascida em 1925, aos 14 anos foi iniciada no candomblé por Mãe Senhora e recebeu o nome de Odé Kayodê. Assumiu a direção do Ilê Axé Opó Afonjá em 1976, tornando-se a sua quinta iyalorixá. Escreveu sete livros sobre religiões afro-brasileiras. 


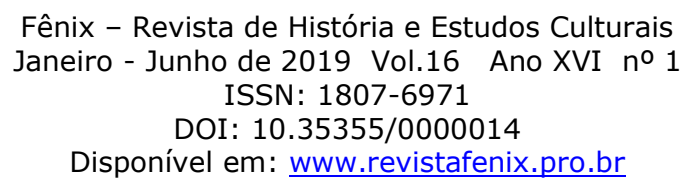

e não uma seita sincretizada", escreveu um manifesto ${ }^{21}$ que foi assinado também por mais quatro lideranças religiosas de Salvador: as iyalorixás Menininha ${ }^{22}$, do Terreiro do Gantois, Olga, do Terreiro do Alaketu, Tetê de Iansã, do Terreiro da Casa Branca e Nicinha, do Terreiro do Bogum. O texto, embora não publicado na íntegra, foi muito discutido nas rodas de conversa e nos jornais de Salvador, e trazia as seguintes afirmações:

Não podemos pensar, nem deixar que nos pensem como folclore, seita animismo, religião primitiva como sempre vem ocorrendo neste país, nesta cidade, seja por parte de opositores, detratores: muros pichados, artigos escritos - "Candomblé é coisa do Diabo", "Práticas africanas primitivas ou sincréticas", seja pelos trajes rituais utilizados em concursos oficiais e símbolos litúrgicos consumidos na confecção de propaganda turística e ainda nossas casas de culto, nossos templos, incluídos, indicados, na coluna do folclore dos jornais baianos. ${ }^{23}$

Para elucidar alguns pontos do manifesto e responder às críticas, outro documento $^{24}$ foi escrito em 12 de agosto de 1983. Há a afirmação do candomblé enquanto religião e que suas lideranças devem lutar contra a folclorização, o uso político, turístico e comercial de suas divindades, crenças e práticas. Critica o costume dos pais e mães de santo de levarem os iniciados, recém-saídos das camarinhas, à Igreja do Bonfim para assistirem à missa e as visitas guiadas e pagas aos terreiros:

Candomblé não é uma questão de opinião. É uma realidade religiosa que só pode ser realizada dentro de sua pureza de propósito e rituais. Quem assim não pensa, já de há muito está desvirtuado e por isso podem continuar sincretizando, levando Iyaôs ao Bonfim, rezando missas, recebendo os pagamentos, as gorjetas para servir ao polo turístico baiano, tendo acesso ao poder, conseguindo empregos etc. ${ }^{25}$

21 O Manifesto ao Público e ao Povo do Candomblé encontra-se no Museu do Candomblé: Ohun Láíláí, localizado no Ilê Axé Opó Afonjá.

22 Maria Escolástica da Conceição Nazaré (1894-1986), iniciada aos 8 anos pela tia-avó Pulchéria Maria da Conceição (Mãe Pulchéria), era filha de Oxum e iyalorixá do Terreiro do Gantois de 1922 a 1986.

23 Manifesto ao Público e ao Povo do Candomblé. Salvador, 27 jul. 1983, p. 1. Museu do Candomblé: Ohun Láíláí.

24 O documento de 12 de agosto de 1983 encontra-se no Museu do Candomblé e como anexo ao artigo: CONSORTE, Josildeth Gomes. Em torno de um manifesto de ialorixás baianas contra o sincretismo. In: CAROSO, Carlos; BACELAR, Jeferson (orgs.). Faces da tradição afro-brasileira. Rio de Janeiro: Pallas/Salvador: CEAO, 2006. p. 71-91.

25 CONSORTE, Josildeth Gomes. Em torno de um manifesto de ialorixás baianas contra o sincretismo. In: CAROSO, Carlos; BACELAR, Jeferson (Orgs.). Faces da tradição afro-brasileira. Rio de Janeiro: Pallas/Salvador: CEAO, 2006, p. 80-91. 


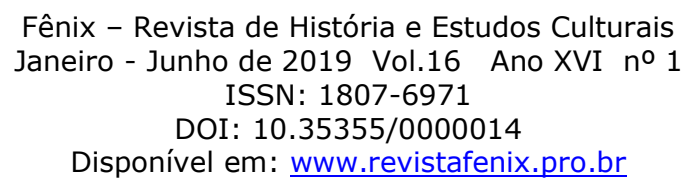

Na literatura produzida na Bahia nos anos 1980 ainda prevalecia a idéia de mistura harmônica entre as práticas culturais e religiosas dos baianos. Nesse enredo da santa e do orixá, ambas capazes de provocar tempestades, Jorge Amado trata da mistura, das fronteiras indistintas entre os costumes e visões de mundo dos baianos:

[...] Terra onde tudo se mistura e se confunde, ninguém é capaz de separar a virtude do pecado, de distinguir entre o certo e o absurdo, traçar os limites entre a exatidão e o embuste, entre a realidade e o sonho. Nas terras da Bahia, santos e encantados abusam do milagre e da feitiçaria, e etnólogos marxistas não se espantam ao ver imagem de altar católico virar mulata faceira na hora do entardecer. ${ }^{26}$

Certamente, Jorge Amado, na condição de Obá de Xangô do Ilê Axé Opô Afonjá e amigo de Mãe Stella, conhecia as polêmicas envolvendo as declarações e o manifesto produzido por ela. Além disso, o livro $O$ sumiço da santa foi escrito entre 1987 e 1988, ou seja, quatro anos após o manifesto. Entretanto, há que se considerar que as separações entre as crenças são geralmente desejadas e oficializadas pelas autoridades religiosas. Os fiéis não estão preocupados com as fronteiras entre as religiões. Estão mais propensos à complementação de práticas distintas, - sem a necessidade, inclusive, de determinar graus de importância.

Dessa forma, o romancista não se sentia responsável pela separação entre práticas católicas e candomblecistas. Permaneceu ligado à imagem da Bahia mística, mestiça e sincrética da baianidade. E ele não foi o único. A própria Stella reconhece o desafio de implementar mudanças mesmo entre o povo de santo, que, de acordo com o documento, já estavam desvirtuados:

Vemos que todas as incoerências surgidas entre as pessoas do candomblé que querem ir à lavagem do Bonfim carregando suas quartinhas, que querem continuar adorando Oyá e S. Bárbara, como dois aspectos da mesma moeda, são resíduos, marcas da escravidão econômica, cultural e social que nosso povo ainda sofre. ${ }^{27}$

26 AMADO, Jorge. O sumiço da santa: uma história de feitiçaria. Rio de Janeiro: Record, 1988. p. 44.

27 CONSORTE, Josildeth Gomes. Em torno de um manifesto de ialorixás baianas contra o sincretismo. In: CAROSO, Carlos; BACELAR, Jeferson (orgs.). Faces da tradição afro-brasileira. Rio de Janeiro: Pallas/Salvador: CEAO, 2006. p. 80-91. 
Em uma entrevista ${ }^{28}$ concedida por Mãe Stella, em 2002, ela conta que uma das mães de santo que assinou o manifesto, ao ser perguntada sobre o mesmo, falou sobre a necessária separação entre as religiões. Porém, o repórter disse: "Dia 4 de dezembro está chegando". Imediatamente a entrevista completou: "Ave Maria, minha mãe... ê parrê... Eu tenho que ver Santa Bárbara!”. Então, se essas marcas sociais, religiosas e culturais permanecem na sociedade baiana, não seria justo cobrar do escritor que o seu romance trouxesse um discurso politicamente correto sobre a religiosidade em Salvador.

E Santa Bárbara não é a única imagem desse enredo a ganhar vida. No capítulo "Giroflê”, Jorge Amado faz entrar o ex-detento Pergentino Quarta-Série na casa de Carybé, local cheio de valiosíssimas obras de arte. Mesmo na escuridão, ele enxergou o vulto de uma mulher adormecida sobre um banco de madeira. Era "uma negra nua", "escultural" e com uma "bunda de ensandecer qualquer mortal". "Pareceu-lhe uma deusa, mas não reconheceu Oyá - Yansã”. O ladrão esqueceu o motivo da sua entrada na casa e, pronto para o ato sexual, se aproximou da beldade, mas nem chegou a tocá-la,

[...] pois no mesmo instante em que empunhou a vara, do alto da estante onde estava colocado, o São Jorge de granito, sem desmontar do cavalo branco, seguido pelo dragão de fogo, saltou sobre ele, investiu com a lança dirigida para os quibas e a estrovenga do galã das armas. $^{29}$

Nesse caso é o santo que se faz homem para expulsar o malfeitor da casa do seu protegido. Carybé, assim como Jorge, era filho de Oxóssi (na Bahia associado a São Jorge) e Obá do Ilê Axá Opó Afonjá. Segundo Jorge Amado, Quarta-Série esqueceu dessa importante informação sobre Carybé, que “chama-se Obá Onã Xocun, no terreiro senta-se ao lado direito de mãe Stela de Oxóssi, a iyalorixá". ${ }^{30}$

Jorge amado recorre à mistura religiosa, a Bahia mística, "da magia, dos feitiços e da fé" cantada por Herivelto Martins. Porém, é perceptível uma separação entre Bárbara e Yansã, com o sumiço da santa e as ações do encantado. Desde o início

\footnotetext{
28 PRETTO, Nelson; SERPA, Luiz Fellipe. (org.). Expressões de sabedoria: educação, vida e saberes. Salvador: EDUFBA, 2002. p. 48-49.

29 AMADO, Jorge. O sumiço da santa: uma história de feitiçaria. Rio de Janeiro: Record, 1988. p.112.

30 Ibid., p.111.
} 


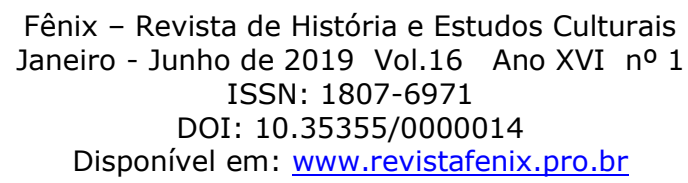

do livro, Jorge Amado alternou os capítulos, buscando a harmonia entre as narrativas sobre a santa (ou a falta dela) e o orixá. O primeiro, "Travessia", como o próprio título indica, trata da viagem da imagem de Santo Amaro da Purificação a Salvador. O segundo, "A entrevista coletiva", sobre a expectativa dos organizadores da exposição e dos profissionais de imprensa pela chegada da imagem ao museu. E assim por diante, um capítulo trata de Yansã e outro do desaparecimento da santa. Portanto, o enredo se divide entre a busca desesperada do diretor do MAS, dom. Maximiliano von Gruden, pela imagem sacra e a visitação de Yansã em diferentes pontos da cidade. Entretanto, a santa some e o orixá ganha destaque. É Oyá quem toma as rédeas do romance.

É possível se pensar numa supremacia do candomblé. A santa do catolicismo, vertente do cristianismo ainda preponderante no Brasil àquela altura, desaparece e dá lugar ao orixá, representante também de um grupo, o nagô, dominante na hierarquia do candomblé baiano a partir de 1870, quando o carisma de suas lideranças e a proximidade com intelectuais e estudiosos e a publicação de suas obras nas primeiras décadas do século XX favoreceram uma maior visibilidade dessas crenças. ${ }^{31} \mathrm{~A}$ hegemonia nagô permaneceu inclusive nas letras das canções das décadas de 1940 e 1950 inspiradas na religiosidade afro-baiana e com referências aos orixás. No livro $O$ sumiço da santa: uma história de feitiçaria há uma valorização do candomblé nagô, com o predomínio de suas entidades, dos seus ritos e das suas práticas.

Porém, a supremacia nagô não impede a mistura dos elementos religiosos. Em outro momento do romance, ao descrever a Festa do Bonfim, também criticada no manifesto, o escritor trata da fusão entre os santos católicos e os orixás.

Chegado de Portugal, ao tempo da colônia, no voto aflito de um náufrago lusitano, Nosso Senhor do Bonfim; chegado da costa da África, ao tempo do tráfico dos negros, no lombo em sangue de um escravo, Oxalá. Sobrevoam a procissão, encontram-se no seio das baianas, mergulham na água-de-cheiro e se confundem, são uma única divindade brasileira. ${ }^{32}$

31 PARÉS, Luis Nicolau. O processo de "nagoização" no Candomblé baiano. In: BELLINI, Lígia; et al. Formas de crer: ensaios de história religiosa do mundo luso-afro-brasileiro, séculos XIV-XXI. Salvador: EDUFBA / Corrrupio, 2006. p. 299-329.

32 AMADO, Jorge. O sumiço da santa: uma história de feitiçaria. Rio de Janeiro: Record, 1988. p. 53. 
É certo que as duas entidades e seus cultos chegaram à Bahia durante o período colonial. A imagem do Cristo Crucificado veio de Setúbal - Portugal como pagamento de promessa de Theodózio Rodrigues de Farias (capital de mar e guerra e traficante de escravos) ao Senhor do Bonfim por tê-lo livrado de um naufrágio. Juntamente com outros portugueses, em 1745, fundou uma irmandade, Devoção do Senhor Bom Jesus do Bonfim, e providenciou a construção da igreja, inaugurada em $1754 .{ }^{33}$

A escravidão forçou a realização do culto dos deuses africanos no mesmo espaço, muitas vezes no mesmo terreiro e ainda levou a associação de características similares desses com os santos, mas eles não formam uma mesma divindade, apenas são cultuados no mesmo dia nas ruas, praças e adros das igrejas. As homenagens aos orixás foram incorporadas ao calendário das festas católicas. Assim, em 04 de dezembro, na festa oficialmente instituída para Santa Bárbara também se louva Yansã e na festa do Senhor Bom Jesus do Bonfim, Oxalá.

É difícil precisar o início do cortejo que percorre cerca de oito quilômetros entre a Igreja de Nossa Senhora da Conceição da Praia à Igreja do Senhor do Bonfim. Os primeiros relatos são do século XVIII, mas é provável que a Lavagem do Bonfim tenha se iniciado por volta de 1804 , quando a mesa administrativa da irmandade permitiu que as devotas de São Gonçalo cultuassem o patrono na mesma igreja. Elas, então, cuidavam dos ornamentos e limpeza do templo, assim como nos terreiros há o costume lavar a indumentária dos iniciados, os assentamentos e objetos rituais dos orixás antes do dia da festa. ${ }^{34}$ Dessa forma, essas mulheres, vestidas de branco e com os panos da costa, lavavam a igreja com água aromatizada com as folhas sagradas e flores, a água de cheiro.

Dessa forma, temos o encontro das entidades católicas e do candomblé nos mesmos espaços, a avenida sacralizada para o cortejo e a igreja. Mircea Eliade ${ }^{35}$ defende que o homem religioso tem a necessidade de sacralizar os espaços caóticos, profanos, povoados de seres estranhos, espectros, demônios. É preciso torná-los o

33 COUTO, Edilece Souza. Jesus e Oxalá: devoção e festa em Salvador-BA. In: CARREIRO, Gamaliel; et al . Religião, carisma e poder: as formas da vida religiosa no Brasil. São Paulo: Paulinas, 2015. p. 141.

34 Ibid., p. 144-145.

35 ELIADE, Mircea. O sagrado e o profano: a essência das religiões. Lisboa: Edições "Livros do Brasil", 1999, 240p. 


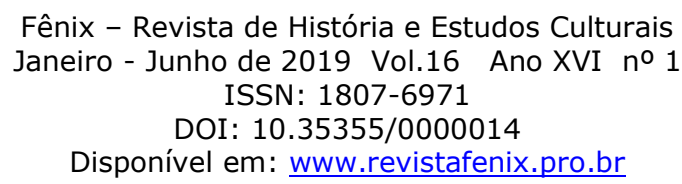

cosmo, o nosso mundo, o lugar dos deuses. Assim acontece nas procissões e cortejos religiosos. As ruas percorridas pelos fiéis são lavadas com água de cheiro, as janelas das casas e sobrados são ornamentadas com toalhas brancas e bordadas, vasos de flores, imagens dos santos e orixás.

É muito comum as baianas e demais fiéis carregarem no peito crucifixo e as guias, colares de contas consagradas e nas cores das entidades afro-brasileiras de devoção. Esses elementos estão juntos, representam diferentes divindades, mas não significa que elas se misturam. O devoto que as carregam, sabem diferenciar Jesus e os santos dos orixás, enquices, voduns, caboclos, etc. Porém, é preciso destacar que essas representações não são excludentes, e sim, complementares na vivência religiosa de duas ou mais crenças. Portanto, a presença de símbolos de diferentes credos no mesmo espaço ou no corpo de um crente, pode passar a idéia de fusão entre as entidades, quando são elementos identitários de crenças que se complementam.

\section{FESTAS E RITOS AFRO-CATÓLICOS}

Nas obras de Jorge Amado, muitos acontecimentos (encontros de amigos e familiares, namoros, violência e intrigas) se dão nos dias e nos espaços das festas católicas, do candomblé e do Carnaval. Em $O$ sumiço da santa não podia ser diferente. Assim que Bárbara saiu do andor, se transformou em Yansã, que "ajeitou as pregas do manto e se mandou". O orixá subiu a rampa do mercado, caminhou em direção ao Elevador Lacerda e "Levava certa pressa, pois a noite se aproximava e já era passada a hora do padêt 36 " 37

O terceiro capítulo é denominado "Festa". Enquanto o diretor do MAS se inquietava com a demora para a chegada da imagem de Santa Bárbara, Yansã, antes que as luzes da cidade se acendessem, "vestida com as cores do crepúsculo", atravessou a porta do Gantois, um dos principais terreiros de candomblé da Bahia, e se prostrou em frente a iyalorixá Menininha. Ao ser levantada, acolhida com um abraço pela mãe de santo, Oyá soltou seu grito, com “As mãos na cintura, salvou a roda e a orquestra e, a

\footnotetext{
36 Padê é o ritual propiciatório com oferenda a Exu. É realizado antes de qualquer cerimônia pública ou privada.

37 AMADO, Jorge. O sumiço da santa: uma história de feitiçaria. Rio de Janeiro: Record, 1988. p. 21.
} 
seguir, salvou alguns antigos e notáveis, detendo-se diante deles para abraçá-los, peito contra peito, coração contra coração". ${ }^{38}$

Porém, Yansã ficou pouco tempo no terreiro, pois, tinha muito que fazer, veio para terminar uma tarefa iniciada no mês de janeiro, na quinta-feira da Lavagem do Bonfim. Nas religiões afro-brasileiras, se festeja para homenagear as entidades. O momento também é propício para consultas e pagamento de promessas. Para os encantados, é hora de dançar, beber e, se alimentar das comidas rituais, mas, também, de orientar seus filhos, repreendê-los, se necessário. É hora do acerto de contas. E na trama de Jorge Amado esse era o propósito de Yansã. Ela veio para guerrear, fazer justiça, libertar Manela do cativeiro imposto pela tia Adalgisa, a quem o orixá pretendia "ensinar a tolerância e a alegria, o bom da vida" 39 , ou seja, "proclamar o direito à vida e ao amor". 40

Apesar do manifesto contra o sincretismo, ainda é comum filhos e filhas de santo terminarem suas iniciações do candomblé na Igreja do Bonfim. Participar da festa do Senhor Bom Jesus do Bonfim e de Oxalá na segunda quinta-feira após o dia de Reis, em janeiro, é o último ato sagrado. O santo já foi feito, já se sabe, portanto, quem rege a cabeça do iniciado. Porém, é possível que o encantado se manifeste sem preparação. Foi o que aconteceu com a personagem Manela.

Após a morte dos pais, Manela foi viver com a tia Adalgisa, uma católica fervorosa, sempre assustada com a possibilidade de pecar e queimar no fogo do inferno. Educava a sobrinha com rigidez. A irmã da menina, Marieta, ficou sob os cuidados da outra tia, Gildete, viúva de um barraqueiro do Mercado, mãe de três filhos, moradora do Tororó, professora e, o mais importante, adepta do candomblé. ${ }^{41}$

No dia da Lavagem do Bonfim, Gildete levou a filha Violeta e a sobrinha Manela à festa. Chegaram cedo à Igreja de Nossa Senhora da Conceição da Praia, local de partida do cortejo. Misturaram-se às baianas vestidas com os trajes brancos rituais:

[...] a saia rodada, as anáguas engomadas, a bata de rendas e bordados, as sandálias de taco baixo. Ostentavam, nos braços e no colo,

\footnotetext{
38 Ibid., p. 33-34.

39 AMADO, Jorge. O sumiço da santa: uma história de feitiçaria. Rio de Janeiro: Record, 1988. p. 38.

40 Ibid., p. 153.

41 Ibid., p. 51-52.
} 


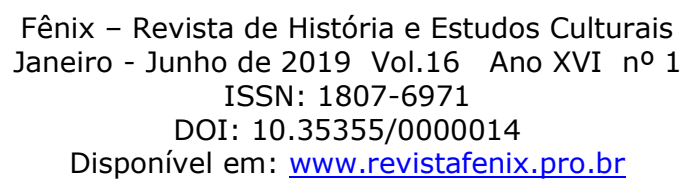

balangandãs de prata, adereços e pulseiras com as cores de seus santos. Pote, jarro ou moringa sobre o turbante, na cabeça: água-decheiro para a obrigação. Mães e filhas-de-santo de todas as nações afro-baianas - nagô, jeje, ijexá, angola, congo. E da nação cabocla, no dengue a na alegria. ${ }^{42}$

Manela era só animação. Na saída do cortejo, as baianas na frente, seguidas de jegues carregados de barris de água de cheiro e enfeitados com flores e folhagens. Nas carroças e no chão, famílias inteiras, músicos, blocos e afoxés tocavam violões, acordeons, cavaquinhos, tamborins e berimbaus. Ouviam-se hinos religiosos, de preceito, sambas e frevos. O governador, o prefeito, os vereadores e outros candidatos nas próximas eleições disputavam espaço e distribuíam abraços, sorrisos e cumprimentos aos possíveis eleitores. Vinha gente de todo lado. Desciam as ladeiras, saiam da Feira de São Joaquim, desembarcavam dos ferry-boats, lanchas e saveiros.

A subida da ladeira se inicia aos sons dos atabaques, ao canto dos afoxés, são as águas de Oxalá. A massa do povo se dirige para a Basílica, que está fechada por decisão da Cúria. Antes lavava-se a Igreja inteira, celebrava-se Oxalá no altar de Jesus, um dia voltará a ser assim. As baianas ocupam o átrio e a escadaria, a lavagem começa, cumpre-se a obrigação de candomblé: Exê-ê-babá!"' ${ }^{33}$

Manela era filha de Yansã, recebeu o orixá pela primeira vez na Lavagem do Bonfim. Foi o próprio Oxolufã, o Oxalá velho, associado ao Cristo Crucificado, e também homenageado na lavagem das escadas da Igreja do Bonfim, quem abraçou a moça e "Ao afastar-se, salvou bem alto para que soubessem: Eparrei!, e as baianas repetiram, curvando-se diante de Manela: Eparrei!". ${ }^{44}$

Yansã partiu tão de súbito como veio. Levou embora, para enterrar no mato, a imundície acumulada, toda aquela porcaria: a pusilanimidade e a submissão, a ignomínia e o fingimento, o medo das ameaças e dos gritos, dos tapas na cara, da taca de couro pendurada na parede e, pior que tudo, dos pedidos de perdão. Oyá limpara o corpo de Manela, fizera-lha a cabeça. ${ }^{45}$

\footnotetext{
42 Ibid., p. 52.

43 AMADO, Jorge. O sumiço da santa: uma história de feitiçaria. Rio de Janeiro: Record, 1988. p. 53.

44 Ibid., p. 62.

45 Ibid., p. 62.
} 


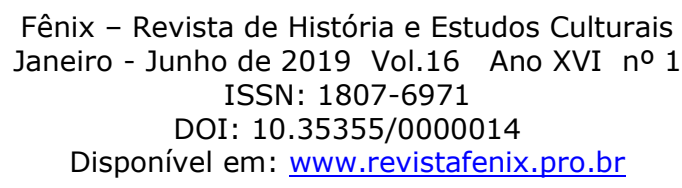

Manela, leve e faceira, não tinha mais medo da tia Adalgisa. A festa foi um divisor de águas na vida da moça. Após o ritual da lavagem do adro e da escada da igreja, as baianas, desfeitas do transe, ajoelhavam e rezavam pedindo as bênçãos do Senhor do Bonfim. Um padre, "pardo e idoso", caminhou até a porta para apreciar a festa no largo. Lembrava-se do tempo em que se lavava toda a igreja e "nunca percebera na cerimônia falta de fé, de devoção, sinal de desrespeito". ${ }^{46}$ Não entendia por que seus superiores proibiram a celebração.

A lavagem dos templos católicos estava proibida desde dezembro de 1889, por meio de portaria do arcebispo dom Luís Antônio dos Santos que exortava os padres a procederam a limpeza da casa de Deus, sem anúncio prévio nem ajuntamento, com decência e reverência. No dia da Lavagem do Bonfim, em janeiro de 1890, as portas da igreja permaneceram fechadas e guardadas pela polícia. ${ }^{47}$ Assim, restava aos adeptos do candomblé lavar o adro e a escada, mantendo o ritual. Apesar da interdição por parte da alta hierarquia da Igreja Católica e da vigilância pela polícia, sempre houve padres baianos tolerantes com as práticas híbridas entre o catolicismo e as religiões afrobrasileiras, alguns dispostos a burlar ou fazer vistas grossas às regras, serem ecumênicos conhecidos e amigos de Jorge Amado.

A notícia da visitação de Yansã a Salvador se espalhou pelos terreiros e pelas barracas do Mercado de Santa Bárbara ${ }^{48}$, na Baixa dos Sapateiros, onde existe um nicho com a imagem da padroeira e também se bate atabaques e rodas são realizadas para o orixá. O Mercado se vestiu de vermelho e branco, as cores das homenageadas. Barracas receberam guirlandas, bandeirolas, flores de papel crepom, "se bem ainda estivesse distante a festa de Yansã que ali se comemora a 4 de dezembro". Uma de suas filhas, Jacira do Odô Oyá, "improvisou um modesto caruru ${ }^{49}$ de 12 grosas de quiabos". 50

46 Ibid., p. 66.

47 COUTO, Edilece Souza. Jesus e Oxalá: devoção e festa em Salvador-BA. In: CARREIRO, Gamaliel; et al. Religião, carisma e poder: as formas da vida religiosa no Brasil. São Paulo: Paulinas, 2015. p. 149-151.

48 COUTO, Edilece Souza. Bárbara e Iansã, as donas dos mercados de Salvador. In: RUBIM, Linda; MIRANDA, Nadja (Orgs). Estudos da Festa. Salvador: Edufba, Coleção Cult, 2012. p. 111-131.

49 Na culinária afro-baiana o caruru ou efó é feito com quiabos. Eles são cortados miúdos e cozidos, temperados com camarão seco, farinha de amendoins e castanhas de caju, cebola, alho, coentro e azeite de dendê. É servido nas festas de Santa Bárbara, Yansã e dos ibeji (encantados que são crianças gêmeas associadas a São Cosme e São Damião). Na Bahia se mede o tamanho do caruru pela quantidade de quiabos, normalmente centenas ou milhares. Portanto, um caruru de 144 quiabos é mesmo modesto. 


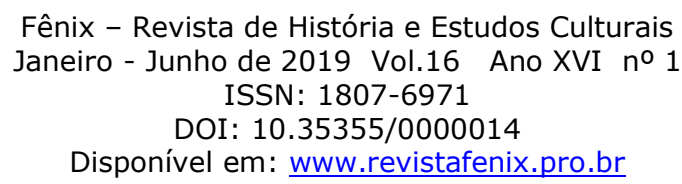

A festa de 04 de dezembro abre o calendário das festas religiosas do verão de Salvador. Oficialmente a homenageada é Santa Bárbara, mas, é provável que desde o século XVII, quando foi construído na cidade baixa, área comercial e portuária, o Mercado de Santa Bárbara e a capela, os trabalhadores, em grande parte, africanos e descendentes, após a procissão católica e a volta da santa para o seu altar, festejavam Yansã com batuques e banquetes regados a azeite de dendê. O marcado de mesmo nome na Baixa dos Sapateiros foi inaugurado em 1912 e, junto com a casa do Corpo de Bombeiros, permanece como um dos importantes pontos de parada da procissão de Santa Bárbara e distribuição de caruru no dia 4 de dezembro. ${ }^{51}$

Yansã visitou alguns terreiros, nos quais dançou, distribuiu bênçãos aos seus filhos e suas filhas, recebeu os ebós e se alimentou. No entardecer da quarta-feira visitou o Gantois e no dia seguinte,

Na barra da manhã daquela quinta-feira Oyá foi vista em ruas e becos, no centro e nas aforas da cidade da Bahia, indo de axé em axé, em visitação. Se, devido aos chifres de búfalo e ao cuspo de fogo, alguém a reconheceu, não revelou espanto, não fez escândalo, não se atirou a seus pés nem lhe proclamou o nome. Saudou-a com descrição, num sussurro da boca para dentro. Somente ela e mais ninguém poderia percebê-lo: Eparrei! $!^{52}$

Assim começa o capítulo "O ebó" ${ }^{53}$ Jorge Amado faz referência aos principais símbolos e características de Yansã, mencionados em seus mitos.

Os chifres de búfalo é uma referência ao fato de Oyá transformar-se em um búfalo. Ogun estava na floresta quando viu a mulher sair do animal e esconder sua cabeça e sua pele. Ele levou a trouxa consigo e passou a cortejar Oyá. Ela voltou ao local do esconderijo e não encontrou nada. Desconfiou de Ogun e disse que se casaria com ele, mas ninguém deveria saber que ela era um animal. Ela era bela, teve nove filhos e provocou ciúme e a hostilidade das outras esposas de Ogun. Uma delas o embriagou e ele revelou o segredo de Yansã. Porém, ela descobriu os chifres e a pele de búfalo, se vestiu e massacrou as outras mulheres. Logo após, ela entregou os chifres aos

50 AMADO, Jorge. O sumiço da santa: uma história de feitiçaria. Rio de Janeiro: Record, 1988. p. 153.

51 COUTO, Edilece Souza. Bárbara e Iansã, as donas dos mercados de Salvador. In: RUBIM, Linda; MIRANDA, Nadja (Orgs). Estudos da Festa. Salvador: Edufba, Coleção Cult, 2012. p. 111-131.

52 AMADO, Jorge. O sumiço da santa: uma história de feitiçaria. Rio de Janeiro: Record, 1988. p. 153.

53 Ebó é a oferenda ou o sacrifício de animal para uma divindade do candomblé. 


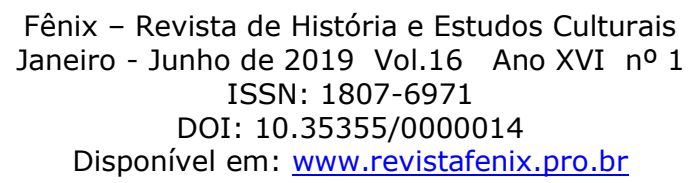

filhos dizendo que toda vez que precisassem dela, esfregassem os dois chifres que ela viria socorrê-los. Geralmente há dois chifres no peji ${ }^{54}$ de Yansã. ${ }^{55}$

Outro mito explica por que Oyá cospe fogo. Um dia Oyá foi enviada por Xangô para uma terra distante. Ela deveria transportar uma porção que, quando ingerida, fazia cuspir fogo pela boca e pelo nariz. No trajeto de volta, a curiosidade a consumia. Ela usou a fórmula e, desde então, possui o mesmo poder do seu marido. ${ }^{56}$

Naquela manhã de quinta-feira enquanto Olga ${ }^{57}$ jogava os búzios, percebeu os sinais de que sua mãe Yansã estava chegando. “Oyá se mostrou e acendeu a aurora no sopé da ladeira do Alaketu”. E “A cabra, presa por uma corda atrás do barracão, berrou aflita”. A chegada do encantado ainda foi sentida por outra personagem, uma jovem iniciada e filha de Yansã: "Acocorada diante da gamela de acarajés, a moça enxergou apenas a luz da aurora rompendo as trevas, mas distinguiu fulgurações grenás, estrias cor de vinho e as tomou como signos favoráveis". 58

No Mercado de Santa Bárbara, Yansã foi presenteada com um caruru. Neste trecho do romance, surgem mais duas comidas de Yansã: cabra e acarajés. ${ }^{59}$

Oyá, tendo regressado e decidido, montou Olga, seu cavalo ${ }^{60}$ favorito, empunhou o sabre e saiu dançando. Por três vezes cuspiu fogo antes de acolher no peito a pedinchona e aceitar o ebó. A gamela com os acarajés foi posta no peji, mas quando, quente e vermelho, o sangue espirrou do pescoço da cabra, Oyá o sugou com avidez. Mandou que os pedaços do bicho fossem cozinhados e, separada a sua porção, a sobra servisse de repasto ao povo do axé no fim da tarde. Assim se fez. ${ }^{61}$

54 Peji é o altar de uma divindade afro-brasileira, onde são colocados os seus assentamentos.

55 PRANDI, Reginaldo. Mitologia dos Orixás. São Paulo: Companhia das letras, 2001. p. 297-299.

56 Ibid., p. 308.

57 A personagem Olga é Olga Francisca Régis (1925 - 2005). Ela foi mãe de santo do candomblé Ilê Maroiá Láji, iniciada como filha de Yansã, começou sua atuação em 1948, estendendo seus trabalhos em Salvador até a década de 1970, quando se mudou para São Paulo-SP.

58 AMADO, Jorge. O sumiço da santa: uma história de feitiçaria. Rio de Janeiro: Record, 1988. p. 154.

59 Acarajé é um bolinho feito de feijão fradinho descascado, ralado, temperado com sal e cebola e frito no azeite de dendê.

60 Montar o cavalo é uma expressão utilizada nas religiões afro-brasileiras para dizer que a divindade incorporou um iniciado em transe.

61 AMADO, Jorge. O sumiço da santa: uma história de feitiçaria. Rio de Janeiro: Record, 1988. p. 155. 
A comida ritual, e que faz parte do banquete das festas para Oyá, recebeu um capítulo especial no final do romance: "O caruru". Jorge Amado coloca entre os convivas da barraqueira Jacira alguns babalorixás e iyalorixás de Salvador. E Oyá chega montando seu mais novo cavalo, Adalgisa, para assombro de todos, principalmente do marido Danilo que nunca vira a esposa em caruru. Terminada a festa, o orixá entrega Adalgisa ao babalorixá Luís da Muriçoca para que cuidasse dela. Yansã libertou sua nova filha "da dor de cabeça, do fanatismo, da ruindade" 62 e era chegado o momento dela entrar pra camarinha e ser iniciada.

Manela e Adalgisa receberam Yansã pela primeira vez em locais públicos, o adro da Igreja do Senhor do Bonfim e a praça próxima ao Terreiro do Gantois, respectivamente. Porém, esses espaços são sacralizados pelos fiéis do catolicismo, do candomblé e da umbanda e, por vezes, pelos adeptos das três vertentes religiosas. As entidades podem se manifestar pela primeira vez em qualquer lugar. Depois, os escolhidos como filhos são encaminhados aos terreiros ou centros, locais apropriados para a iniciação, o aprendizado das obrigações, dos mitos e ritos. Ao escolher os cenários, mais uma vez o escritor nos coloca diante das fronteiras tênues entre a ficção e a construção historiográfica, o vivido e o imaginado, o público e o privado, o sagrado e o profano e as diferentes crenças.

No último capítulo de O sumiço da santa, "Saravá três vezes que eu me vou embora", o escritor apresenta as cenas finais de Santa Bárbara, Yansã e as suas yaós Manela e Adalgisa, e avisa:

Quem quiser saber ainda mais sobre esses assuntos de santeria, de vodun, de candomblé e macumba, de feitas, caboclos e orixás, trate de arrumar um dinheirinho, embarque para a Bahia, capital geral do sonho. [...] Vá a qualquer das duas mil casas de candomblé das diversas nações da África e das nações indígenas, nagô, jeje, ijexá, congo, angola e caboclo, situadas na Bahia, em todas elas será bem recebido, com largueza e fidalguia: sendo de paz pode entrar. ${ }^{63}$

Nesse trecho, quando o escritor se despede dos seus personagens, demonstra sua vinculação ao contexto da baianidade. Por meio das referências à religiosidade, faz um convite às pessoas para que visitem a Bahia, conheçam os terreiros de candomblé e

62 Ibid., p. 397.

63 AMADO, Jorge. O sumiço da santa: uma história de feitiçaria. Rio de Janeiro: Record, 1988. p.423424. 
os encantados. Não basta escrever sobre a cultura baiana, é preciso divulgá-la, dar-lhe visibilidade, familiarizar os leitores com personalidades soteropolitanas.

Neste artigo, não houve a intenção de enquadrar o romance $O$ sumiço da santa em uma determinada fase da carreira de Jorge Amado, tarefa complicada uma vez que não há unidade na sua obra. Num mesmo período é possível identificar livros que tratam do amor, da alegria, da sensualidade e outros cujos enredos podem ser vinculados a uma filiação política, nos quais os personagens vivem as agruras da militância e das perseguições. Embora seus livros não sejam feitos apenas de tensões, mas também de amores. Preferi atentar para os elementos da baianidade, preferencialmente a forma como o escritor narra os ritos e as festas afro-católicas.

Iniciei este artigo com um trecho da música de Herivelto Martins e para finalizá-lo, peço licença para parafrasear Dorival Caymmi: "Você já foi à Bahia, nêga? / Não? / Então vá!". Você já leu Jorge Amado? Não? Então, leia! 
Fênix - Revista de História e Estudos Culturais

Janeiro - Junho de 2019 Vol.16 Ano XVI no 1

ISSN: $1807-6971$

DOI: $10.35355 / 0000014$

Disponível em: www.revistafenix.pro.br 